\title{
Article \\ Allelopathy and Allelopathic Substances of Fossil Tree Species Metasequoia glyptostroboides
}

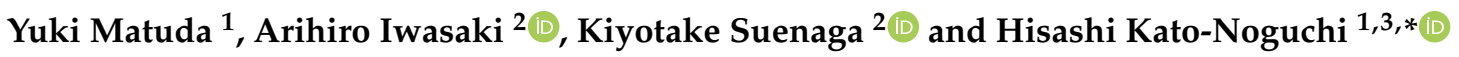 \\ 1 Department of Applied Biological Science, Faculty of Agriculture, Kagawa University, Miki 761-0795, Japan; \\ s20g627@kagawa-u.ac.jp \\ 2 Department of Chemistry, Faculty of Science and Technology, Keio University, Yokohama 223-8522, Japan; \\ a.iwasaki@chem.keio.ac.jp (A.I.); suenaga@chem.keio.ac.jp (K.S.) \\ 3 The United Graduate School of Agricultural Sciences, Ehime University, Matsuyama 790-8566, Japan \\ * Correspondence: kato.hisashi@kagawa-u.ac.jp
}

check for updates

Citation: Matuda, Y.; Iwasaki, A.; Suenaga, K.; Kato-Noguchi, H. Allelopathy and Allelopathic Substances of Fossil Tree Species Metasequoia glyptostroboides. Agronomy 2022, 12, 83. https:// doi.org/10.3390/agronomy12010083

Academic Editor: Antonio Lupini

Received: 10 December 2021

Accepted: 27 December 2021

Published: 30 December 2021

Publisher's Note: MDPI stays neutral with regard to jurisdictional claims in published maps and institutional affiliations.

Copyright: (c) 2021 by the authors. Licensee MDPI, Basel, Switzerland. This article is an open access article distributed under the terms and conditions of the Creative Commons Attribution (CC BY) license (https:// creativecommons.org/licenses/by/ $4.0 /)$.

\begin{abstract}
Metasequoia glyptostroboides Hu et W.C. Cheng is one of the oldest living conifer species, and it has remained unchanged for millions of years compared to its fossils from the Cretaceous period. The species are cultivated in the parks, gardens, and roadsides in many countries. We investigated the allelopathy and allelopathic substances in fallen leaves of M. glyptostroboides. An aqueous methanol extract of the fallen leaves inhibited the growth of cress (Lepidium sativum L.), lettuce (Lactuca sativa L.), alfalfa (Medicago sativa L.), Lolium multiflorum Lam., Phleum pretense L., and Vulpia myuros (L.) C.C.Gmel. The extract was then purified by several chromatographic steps, and two allelopathic substances were isolated and determined by spectral data to be (+)-rhododendrol and 9-epi-blumenol C. The compound inhibited the growth of cress and L. multiflorum. M. glyptostroboides is a deciduous perennial tree, and accumulation of its fallen leaves occur on the soil under the trees. Therefore, those allelopathic substances in the fallen leaves may be liberated into the rhizosphere soil during the decomposition process of fallen leaves and provide a competitive advantage for M. glyptostrob through the growth inhibition of competing plant species nearby. Therefore, M. glyptostroboides is allelopathic, and (+)-rhododendrol and 9-epi-blumenol C may be contribute to the allelopathy.
\end{abstract}

Keywords: allelopathy; fallen leaf; fossil tree; decomposition; mycorrhizal colonization; growth inhibition; phytotoxicity

\section{Introduction}

Metasequoia glyptostroboides Hu et W.C. Cheng, belonging to family Cupressaceae, is a deciduous conifer. The species was found in the 20th century in Southeast China. However, it seems to have remained unchanged for millions of years compared to its fossils of the Cretaceous period (66-145 million years ago) found in several places in the northern hemisphere [1-3]. The species has survived under the several substantial climate, geological, and ecological changes on the earth since the Cretaceous period [4,5]. Morphological characteristics of M. glyptostroboides, such as arrangement of foliage leaves and cataphylls, male strobili, and cone scales, differ from other member of the same family of Cupressaceae [6,7]. In addition, the reproductive characteristics such as seed weight, germination rate, and seedling survival rate were significantly different within the species [8]. However, the reason for the longevity of the species is not clear.

The species has survived under conditions of continuous pathogen attacks, which suggests that the species may have specific compounds involved in the defense systems against the pathogen attacks. Thus, investigations of secondary substances in M. glyptostroboides have been conducted since the 1950s $[9,10]$. A significant number of the secondary substances, such as fatty acids, flavonoids, lignans, and terpenoids, have been isolated and characterized in leaves, stems, and cones including fossil leaves of M. glyptostroboides [11]. 
Terpenoids are the largest group of those secondary substances found in M. glyptostroboides. Dozens of new compounds were also characterized from the species, and majority of new compounds belongs to lignans and norlignans [11]. Lignans are widely distributed in the plant kingdom, but norlignans are mainly distributed in conifers [12].

The essential oil and leaf extracts of $M$. glyptostroboides showed antifungal activity against plant pathogenic fungi such as Botrytis cinereal Pers., Fusarium oxysporum Schlecht. emend. Snyder \& Hansen, Sclerotina sclerotiorum (Lib.) de Bary, Rhizoctonia solani J.G. Kühn, and Phytophthora capsici Leonian [13,14]. Three diterpenoid compounds-taxaquinone, taxodone, and totrarol-were identified in the extracts as antifungal substances $[15,16]$. The extracts also showed antibacterial activity, and diterpenoid compounds suginol and taxodone were identified as antibacterial substances $[17,18]$. Diphenylmethane derivative compound metaseol, which is specific to M. glyptostroboides, was found to have antibacterial activity [19].

The interactions of M. glyptostroboides with the neighboring plant communities including undergrowth species are also crucial to survival. Certain plant secondary metabolites are released into the neighboring environments through volatilization, root exudation, rainfall leaching, and decomposition of the plant parts [20-22]. Some of those compounds have function to disturb the germination and growth of neighboring plants, and suppress the regeneration of those plant species. The phenomenon is defined as an allelopathy. Thus, the allelopathy can provide a competitive advantage for host plants through the inhibition of the growth of competing plant species nearby [23]. Allelopathic active substances also have potential as either herbicides or templates for new herbicide classes [24,25]. It may be possible M. glyptostroboides possesses allelopathic activity and substances because of the longevity of the species. However, there has been no information available on the allelopathic properties of M. glyptostroboides. The objective of this study was the investigation of the allelopathic activity of fallen leaves of M. glyptostroboides, and the isolation of the allelopathic substances in the leaves.

\section{Materials and Methods}

\subsection{Plant Material}

Fallen leaves of M. glyptostroboides were collected on the soil on the campus of Faculty of Agriculture, Kagawa University on December 2017 (Figure 1), and kept at $-20^{\circ} \mathrm{C}$ until extraction. Cress (Lepidum sativum L.), lettuce (Lactuca sativa L.), and alfalfa (Medicago sativa L.) were used to test the allelopathic activity owing to the stable rate of their germination. Three weed species-Lolium multiflorum Lam., Phleum pretense L., and Vulpia myuros (L.) C.C. Gmel.-were used to test the allelopathic activity.

\subsection{Extraction}

Fallen leaves (100 g dry weight) of M. glyptostroboides were cut into small pieces using pruning shears and extracted with 70\% $(v / v)$ aqueous methanol $(2 \mathrm{~L})$ for $48 \mathrm{~h}$. The extract was filtered using filter paper (No. 2; Toyo Ltd., Tokyo, Japan). The residue was then extracted with methanol ( $2 \mathrm{~L}$ ) for $48 \mathrm{~h}$ and filtered. These two extracts were mixed and evaporated to get aqueous solution under reduced pressure at $40^{\circ} \mathrm{C}$.

\subsection{Determination of Allelopathic Activity}

The extract was dissolved with methanol, and an aliquot of the extract solution was added to a sheet of filter paper (No. 2; Toyo Ltd., Tokyo, Japan) in a $2.8 \mathrm{~cm}$ Petri dish. Then, the solution in the Petri dish was evaporated completely using a fume hood, and $0.6 \mathrm{~mL}$ of Tween $20(0.05 \%$, Nacalai, Kyoto, Japan) was added on the filter paper. Ten seeds each of cress, lettuce, and alfalfa, and 10 germinated seeds each of L. multiflorum, P. pretense, and $V$. myuros were placed onto the filter paper in the Petri dishes. Just before the treatments, L. multiflorum, P. pretense, and V. myuros had been germinated on moisten filter paper for $48 \mathrm{~h}$ in the dark at $25^{\circ} \mathrm{C}$. The length of the hypocotyls/coleoptiles and roots of these test plants was measured using a ruler after $48 \mathrm{~h}$-incubation in the dark at $25^{\circ} \mathrm{C}$. The percentage length 
of the hypocotyls/coleoptiles and roots of treatment seedlings was determined against that of each control seedlings. Control seeds were treated exactly same with treatments without the extracts of M. glyptostroboides. The concentrations of the extracts in the Petri dishes were $0.1,1,3,10,30,100$, and $300 \mathrm{mg}$ dry weight equivalent extract $\mathrm{mL}^{-1}$. The concentrations of the extract required for $50 \%$ growth inhibition (defined as $I C_{50}$ ) of the test plant species was determined by the regression equation of the concentration-response curves.

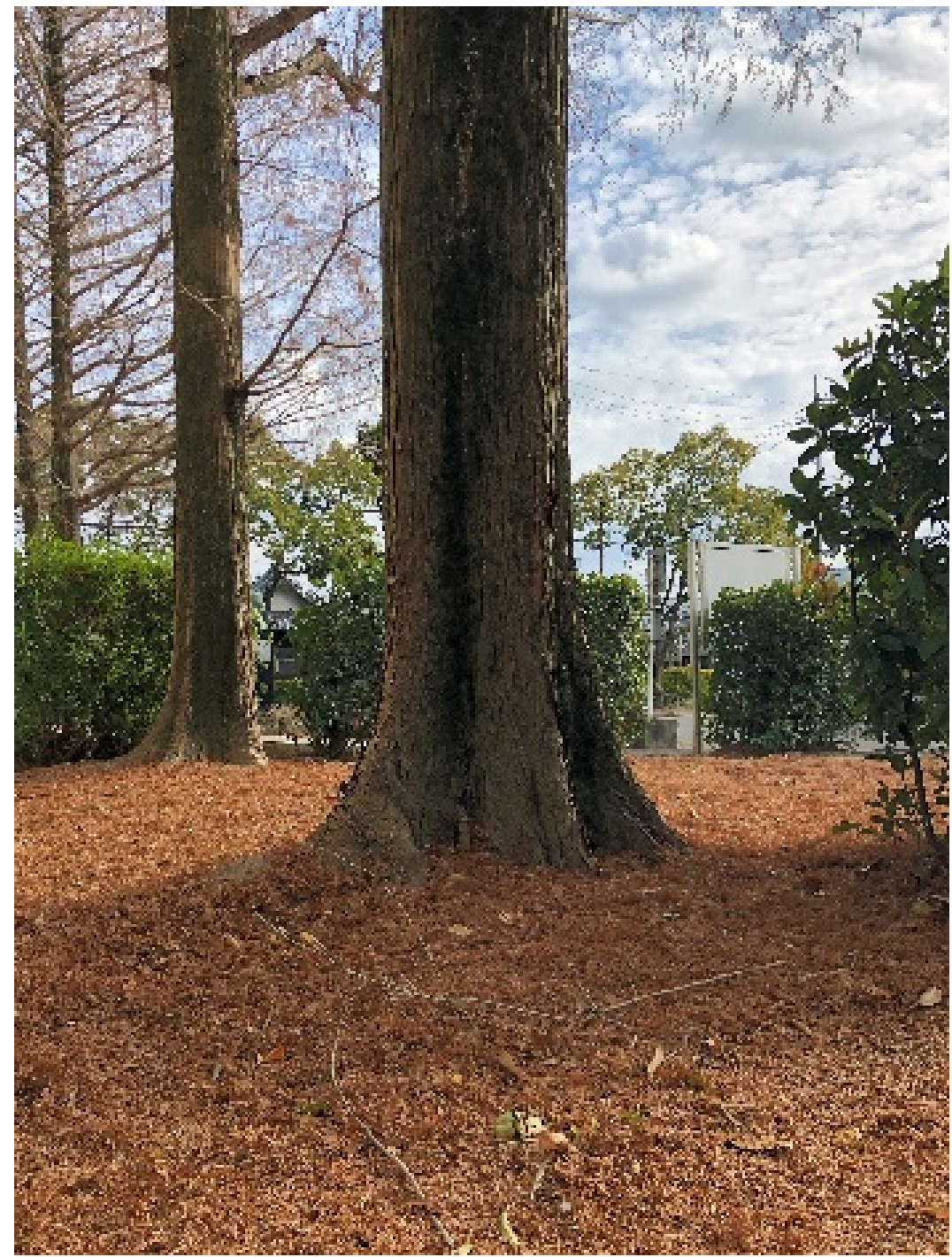

Figure 1. Fallen M. glyptostroboides leaves accumulated on the soil.

\subsection{Separation of M. glyptostroboides Extract}

Fallen leaf pieces of $M$. glyptostroboides (1 kg dry weight) were extracted with $70 \%(v / v)$ aqueous methanol (15 L) for $48 \mathrm{~h}$, and the residues was extracted again with methanol (15 L) for $48 \mathrm{~h}$. Two filtrates were mixed and evaporated to get aqueous solution under reduced pressure at $40{ }^{\circ} \mathrm{C}$ as described above. Then, the aqueous solution was set to $\mathrm{pH} 7.0$ with $1 \mathrm{M}$ phosphate buffer and partitioned three times with ethyl acetate (equal volume of aqueous solution). The resulting ethyl acetate fraction was evaporated to dryness and separated on a silica gel (100 g, silica gel 60, 70-230 mesh; Merck) by chromatography. The chromatography was eluted with 20,30,40,50, 60, 70, and 80\% ethyl acetate in $n$-hexane (100 mL each), ethyl acetate $(100 \mathrm{~mL})$, and methanol $(200 \mathrm{~mL})$. The allelopathic activity of those nine fractions was determined using cress seeds as described above, and activity was found in the two fractions eluted with 60\% ethyl acetate in $n$-hexane (Fraction A) and 80\% ethyl acetate in $n$-hexane (Fraction B). 


\subsection{Isolation of Allelopathic Substance from Fractions $A$ and $B$}

Active Fractions A and B separated by silica gel chromatography were evaporated, and the residues were purified separately by a Sephadex LH-20 (100 g, GE Healthcare Bio-Sciences, Uppsala, Sweden) chromatography and eluted with 20, 30, 40, 50, 60, 70, 80 , and $90 \%(v / v)$ aqueous methanol (100 mL each) and methanol (200 $\mathrm{mL})$. The active fractions were eluted with $40 \%$ aqueous methanol for the Fraction A, and with $30 \%$ aqueous methanol for the Fraction B.

Fraction A was further separated using an ODS cartridge (YMC-Dispo Pack AT ODS25; YMC Ltd., Kyoto) eluted with 30, 40, 50, 60, 70, 80, and 90\% (v/v) aqueous methanol $(150 \mathrm{~mL}$ each) and methanol $(300 \mathrm{~mL})$. The active fraction was eluted by $50 \%$ aqueous methanol. After evaporation, the active fraction was finally separated using reverse-phase HPLC (4.6 i.d. $\times 250 \mathrm{~cm}$, Inertsil ODS-3; YMC Ltd., detection $220 \mathrm{~nm}$ ) eluted at a flow rate of $0.8 \mathrm{~mL}$ with $35 \%$ aqueous methanol. Allelopathic activity was found in a peak fraction eluted between 25-26 min, yielding an active compound 1.

Fraction $B$ was further separated using reverse-phase $C_{18}$ cartridges (YMC Ltd.). The cartridges were eluted with 30,40,50, 60, 70, 80, and 90\% (v/v) aqueous methanol and methanol (15 mL each). The active fraction was eluted with $40 \%$ aqueous methanol. After evaporation, the active fraction was finally separated using reverse-phase HPLC (4.6 i.d. $\times 250 \mathrm{~cm}$, Inertsil ODS-3, detection $220 \mathrm{~nm}$ ) eluted at a flow rate of $0.8 \mathrm{~mL}$ with $35 \%$ aqueous methanol. Allelopathic activity was found in a peak fraction eluted between 118-111 min, yielding an active compound 2. Chemical structures of compounds 1 and 2 were characterized by the analyses of ${ }^{1} \mathrm{H}-\mathrm{NMR}$ spectrum $\left(400 \mathrm{MHz}, \mathrm{CD}_{3} \mathrm{OD}\right)$ and the specific rotation.

\subsection{Allelopathic Activity of Compound 1 and 2}

Each of isolated compounds $\mathbf{1}$ and $\mathbf{2}$ was dissolved with methanol, and an aliquot of the solution was added to a sheet of filter paper in a $2.8 \mathrm{~cm}$ Petri dish. After evaporation of methanol in the Petri dish using a fume hood, the filter paper was moistened with $0.6 \mathrm{~mL}$ Tween 20. Then, 10 seeds of cress and 10 germinated seeds of L. multiflorum were arranged on the filter paper in Petri dishes and grown in the dark at $25^{\circ} \mathrm{C}$ for $48 \mathrm{~h}$. The concentrations of the compounds in the Petri dishes were $0.3,1,3,10,30,100$, and $300 \mu \mathrm{M}$ for compound 1, and 30,100,300, 1000, and $3000 \mu \mathrm{M}$ for compounds 2 , respectively. Allelopathic activity of the of the compounds was then determined as described above. $I C_{50}$ values of the compounds were determined by the regression equation of the concentrationresponse curves.

\subsection{Statistical Analysis}

Determination of allelopathic activity was repeated 2-3 times using a completely randomized design with 10 plants for each determination. Significant difference was analyzed using analysis of variance and followed by Fisher's Least Significant Difference test with SPSS version 16.0.

\section{Results}

\subsection{Allelopathic Activity of Fallen Leaves of M. Glyptostroboides}

Fallen leaf extracts of $M$. glyptostroboides significantly suppressed the hypocotyl and root growth of dicotyledonous plants cress, lettuce, and alfalfa at the concentrations greater than 0.3-10 mg dry weight equivalent extract per $\mathrm{mL}$ (Figure 2). The extract obtained from $10 \mathrm{mg}$ of fallen leaves of $M$. glyptostroboides suppressed the hypocotyl growth of cress, lettuce, and alfalfa by 15.4, 24.1, and 32.1\% of control hypocotyl growth, respectively, and suppressed the root growth of cress, lettuce and alfalfa by $8.0,22.7$, and $33.2 \%$ of control root growth, respectively. 

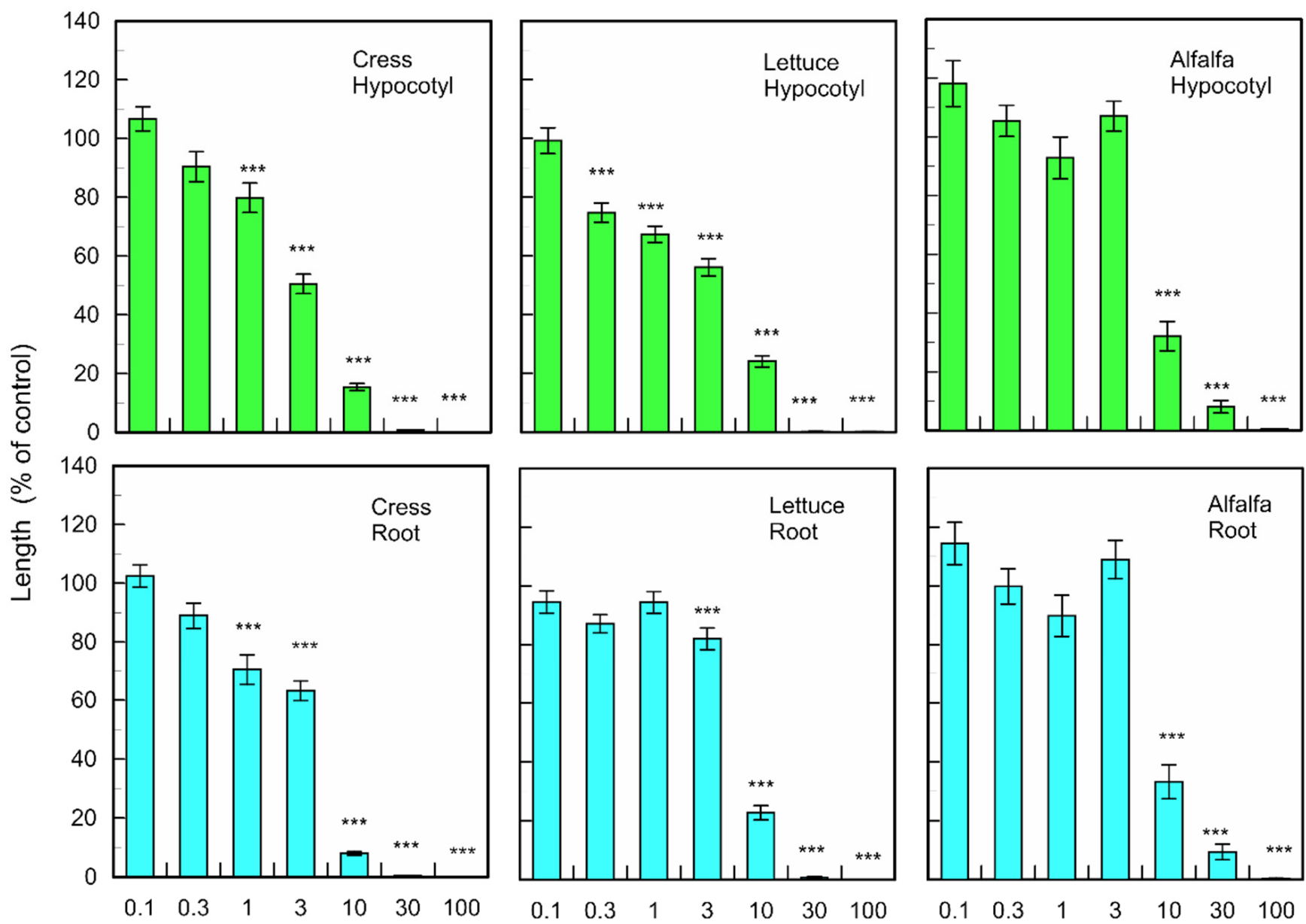

Concentration (mg equivalent extract $/ \mathrm{mL}$ )

Figure 2. Effects of the extracts of M. glyptostroboides leaves on the growth of roots and hypocotyls of cress, lettuce, and alfalfa. Concentrations of tested samples corresponded to the extracts obtained from $0.1,1,3,10,30,100$, and $300 \mathrm{mg}$ dry weight equivalent extract per mL. Means $\pm \mathrm{SE}$ from three independent experiments with 10 plants for each determination are shown. Asterisks indicate significant differences between control and treatment: ${ }^{* * *}, p<0.001$.

The fallen leave extracts also significantly inhibited the coleoptile and root growth of monocotyledonous weed plants; L. multiflorum, P. pretense, and V. myuros at the concentrations greater than $0.3-10 \mathrm{mg}$ dry weight equivalent extract per $\mathrm{mL}$ (Figure 3). The extract obtained from $10 \mathrm{mg}$ of fallen leaves suppressed the coleoptile growth of L. multiflorum, P. pretense, and V. myuros by $51.2,41.6$, and $27.0 \%$ of control coleoptile growth, respectively, and suppressed the root growth of L. multiflorum, P. pretense, and V. myuros by 64.3, 59.7, and $27.9 \%$ of control root growth, respectively (Figure 3). Increasing the concentration of the M. glyptostroboides extract resulted in an increase in inhibition in all test plant species for both dicotyledonous and monocotyledonous plant species (Figures 2 and 3). 

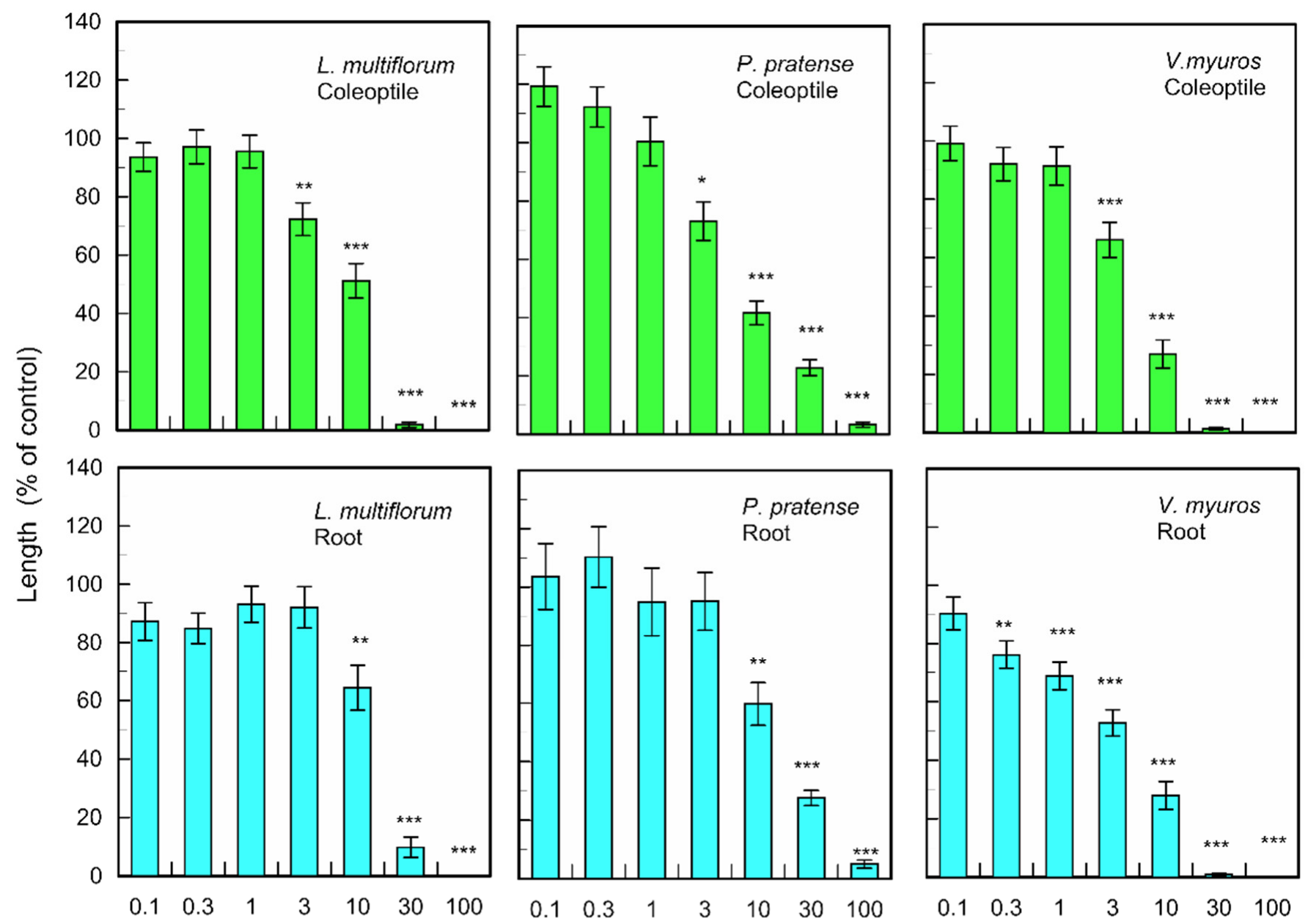

Concentration (mg equivalent extract $/ \mathrm{mL}$ )

Figure 3. Effects of the extracts of M. glyptostroboides leaves on the growth of roots and coleoptiles of L. multiflorum, P. pretense, and V. myuros. Concentrations of tested samples corresponded to the extracts obtained from $0.1,1,3,10,30,100$, and $300 \mathrm{mg}$ dry weight equivalent extract per mL. Means \pm SE from three independent experiments with 10 plants for each determination are shown. Asterisks indicate significant differences between control and treatment: ${ }^{*}, p<0.05,{ }^{* *}, p<0.01,{ }^{* * *}, p<0.001$.

\subsection{Identification of Allelopathic Substances}

The extract of M. glyptostroboides fallen leaves was separated on a silica gel chromatography. The allelopathic activity of all separated fractions was determined by a cress bioassay. Activity was detected in the two fractions eluted with $60 \%$ ethyl acetate in $n$-hexane (Fraction A), and $80 \%$ ethyl acetate in $n$-hexane (Fraction B). Fraction A and $\mathrm{B}$ completely suppressed the growth of the cress hypocotyls and roots at concentration $10 \mathrm{mg}$ dry weight equivalent extract $\mathrm{mL}^{-1}$. Fraction $\mathrm{A}$ and $\mathrm{B}$ were further separated using Sephadex LH-20, and ODS cartridge or reverse-phase $\mathrm{C}_{18}$ cartridge. Finally, two active compounds $\mathbf{1}$ and $\mathbf{2}$ were isolated by HPLC (Figure 4).

Molecular formula of compound $\mathbf{1}$ is $\mathrm{C}_{10} \mathrm{H}_{14} \mathrm{O}_{2}$ as suggested by HRESIMS at $\mathrm{m} / \mathrm{z}$ 167.1079 $[\mathrm{M}+\mathrm{H}]^{+}$(calcd for $\left.\mathrm{C}_{10} \mathrm{H}_{15} \mathrm{O}_{2}, 167.1072\right)$. The ${ }^{1} \mathrm{H}$ NMR $\left(400 \mathrm{MHz}, \mathrm{CD}_{3} \mathrm{OD}\right)$ spectrum of the compound showed $\delta_{\mathrm{H}} 7.00(\mathrm{~d}, J=8.4 \mathrm{~Hz}, 2 \mathrm{H}, \mathrm{H6}, 10), 6.68(\mathrm{~d}, J=8.4 \mathrm{~Hz}, 2 \mathrm{H}$, H7, 9), 3.71 (m, $1 \mathrm{H}, \mathrm{H} 2), 2.61$ (m, $1 \mathrm{H}, \mathrm{H} 4 \mathrm{a}), 2.55$ (m, $1 \mathrm{H}, \mathrm{H} 4 \mathrm{~b}), 1.74-1.59$ (m, $2 \mathrm{H}, \mathrm{H} 3)$, $1.17(\mathrm{~d}, J=6.4 \mathrm{~Hz}, 3 \mathrm{H}, \mathrm{H} 1)$. The optical rotation of the compound was $[\alpha]_{\mathrm{D}}{ }^{25}+39(c 0.12$, $\left.\mathrm{CH}_{3} \mathrm{OH}\right)$. Based on the comparison of these data with those reported in the literature [26,27], the chemical structure of compound was determined to be (+)-rhododendrol (Figure 5). 


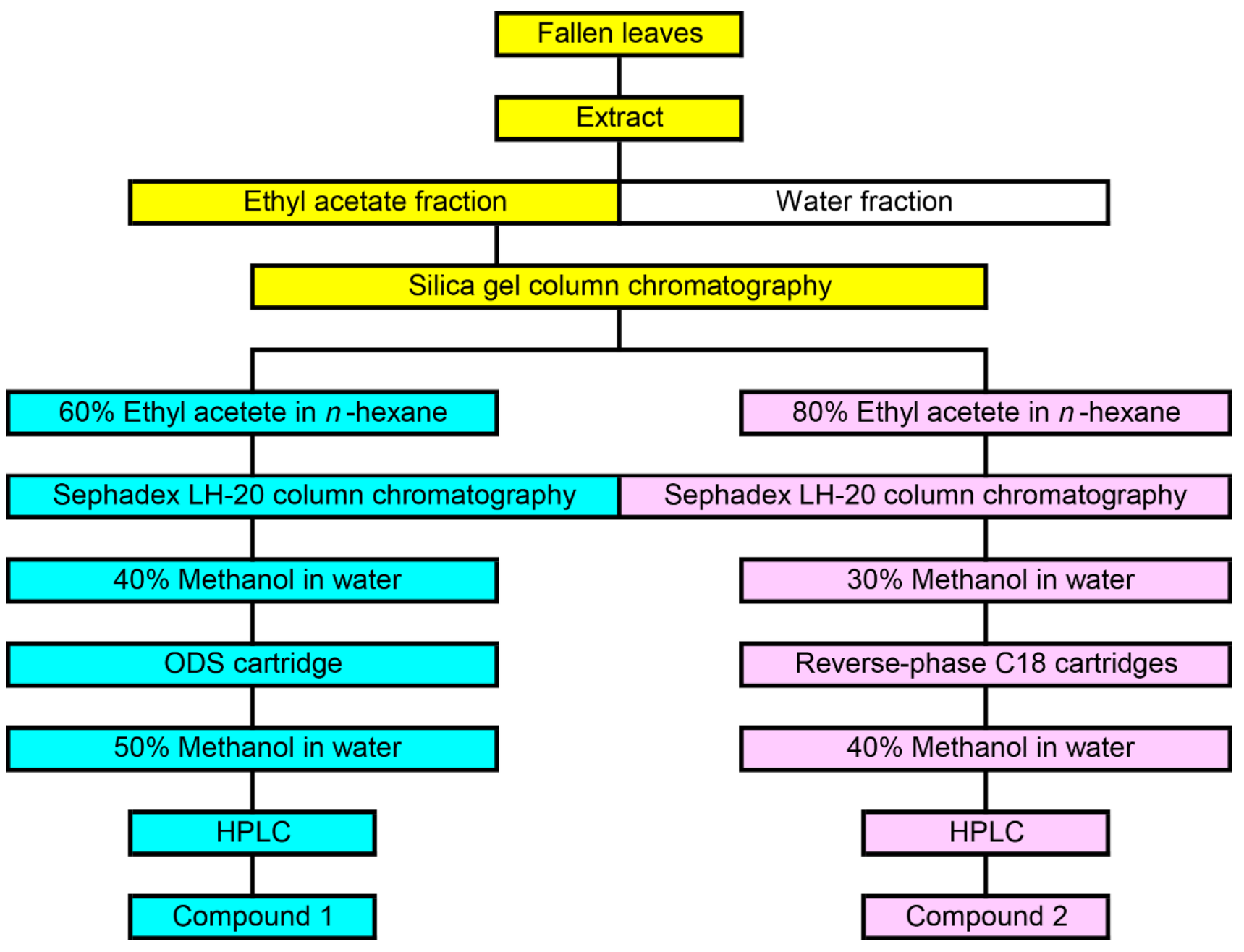

Figure 4. Isolation process of compound 1 and $\mathbf{2}$ from the extract of M. glyptostroboides fallen leaves.

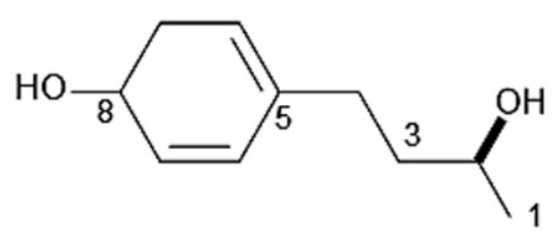

(+)-Rhododendrol<smiles>[Z]C1=CC(=O)CC([Y9])([Y])[C@H]1CC(O)O</smiles>

9-epi-Blumenol C

Figure 5. Chemical structures of (+)-rhododendrol and 9-epi-blumenol C.

Molecular formula of compound 2 is $\mathrm{C}_{13} \mathrm{H}_{22} \mathrm{O}_{2}$ as suggested by HRESIMS at $m / z$ 211.1779 $[\mathrm{M}+\mathrm{H}]^{+}$(calcd for $\mathrm{C}_{13} \mathrm{H}_{23} \mathrm{O}_{2}, 211.1698$ ). The ${ }^{1} \mathrm{H}$ NMR spectrum of the compound showed $\delta_{\mathrm{H}} 5.81$ (s, $\left.1 \mathrm{H}, \mathrm{H}-4\right), 3.69(\mathrm{~m}, 1 \mathrm{H}, \mathrm{H}-9), 2.44(\mathrm{~d}, J=17 \mathrm{~Hz}, 1 \mathrm{H}, \mathrm{H}-2 \mathrm{a}), 2.04(\mathrm{~d}$, $J=1.2 \mathrm{~Hz}, 3 \mathrm{H}, \mathrm{H}-13), 2.00$ (d, J = $17 \mathrm{~Hz}, 1 \mathrm{H}, \mathrm{H}-2 \mathrm{~b}), 1.99$ (m, $1 \mathrm{H}, \mathrm{H}-6), 1.76$ (m, $1 \mathrm{H}, \mathrm{H}-7 \mathrm{a})$, 1.61 (m, 1 H, H-7b), 1.56-1.51 (m, 2 H, H-8), 1.16 (d, J = 6.3 Hz, 3 H, H-10), 1.09 (s, 3 H, H-11), $1.02(\mathrm{~s}, 3 \mathrm{H}, \mathrm{H}-12)$. The optical rotation of the compound was $[\alpha]_{\mathrm{D}}^{27}+90\left(c \mathrm{cos}, \mathrm{CHCl}_{3}\right)$. The chemical structure of the compound was determined to be 9-epi-blumenol C (Figure 5) by the comparison of those spectrum data with published data in the literature [28]. 


\subsection{Allelopathic Activity of Isolated Compounds}

(+)-Rhododendrol significantly suppressed the growth of cress hypocotyls and roots at concentrations greater than $10 \mu \mathrm{M}$, and the growth of L. multiflorum coleoptiles and roots at concentrations greater than 3 and $30 \mu \mathrm{M}$, respectively (Figure 6). 9-epi-Blumenol C significantly inhibited the growth of cress hypocotyls and roots at concentrations greater than $1000 \mu \mathrm{M}$, and the growth of L. multiflorum coleoptiles and roots at concentrations greater than 1000 and $300 \mu \mathrm{M}$, respectively (Figure 7).

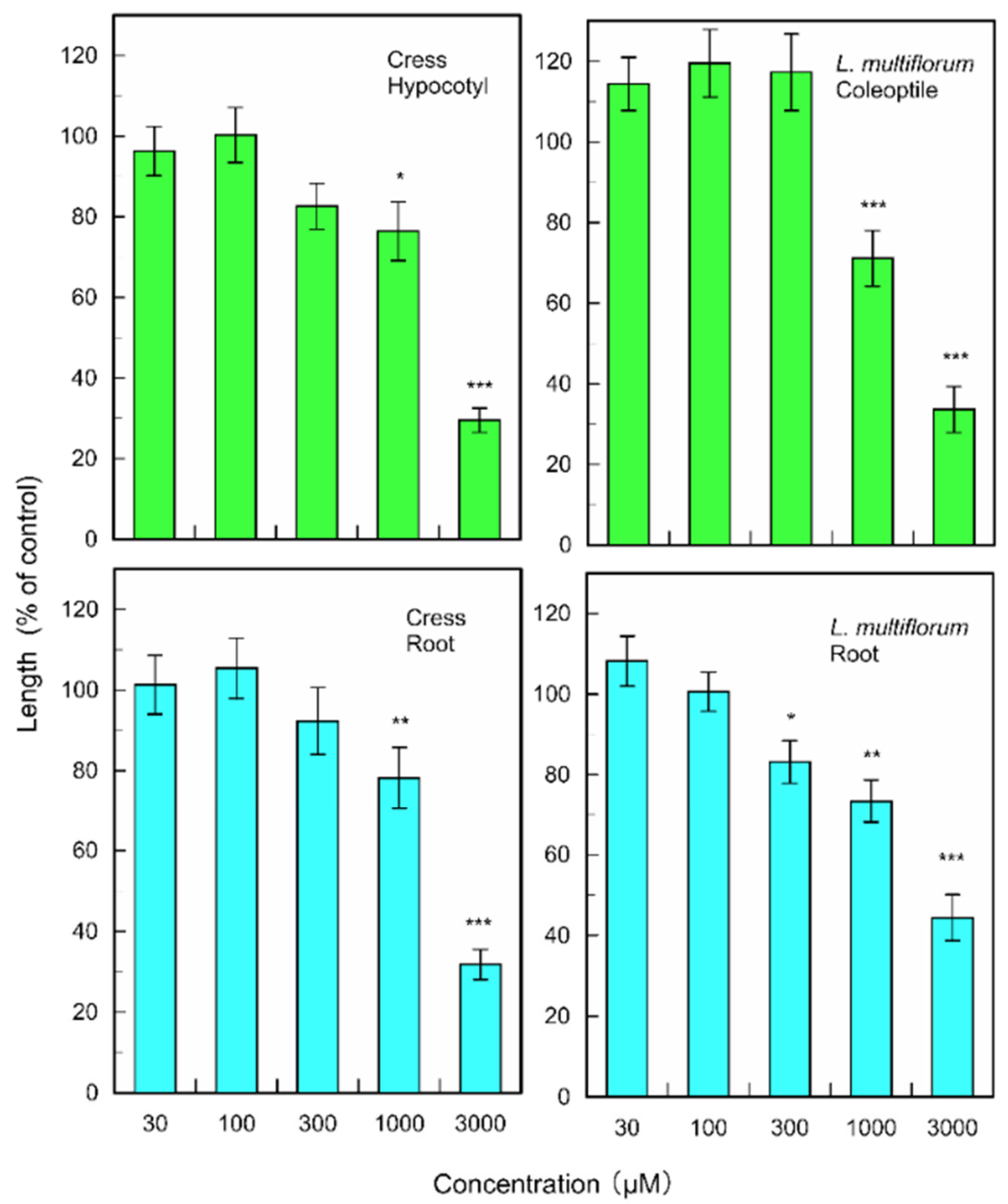

Figure 6. Effects of (+)-rhododendrol on root and hypocotyl/coleoptile growth of cress and L. multiflorum. Means \pm SE from 2 independent experiments with 10 seedlings for each determination are shown. Asterisks indicate significant differences between control and treatment: ${ }^{*}, p<0.05$, $* *, p<0.01,{ }^{* * *}, p<0.001$. 

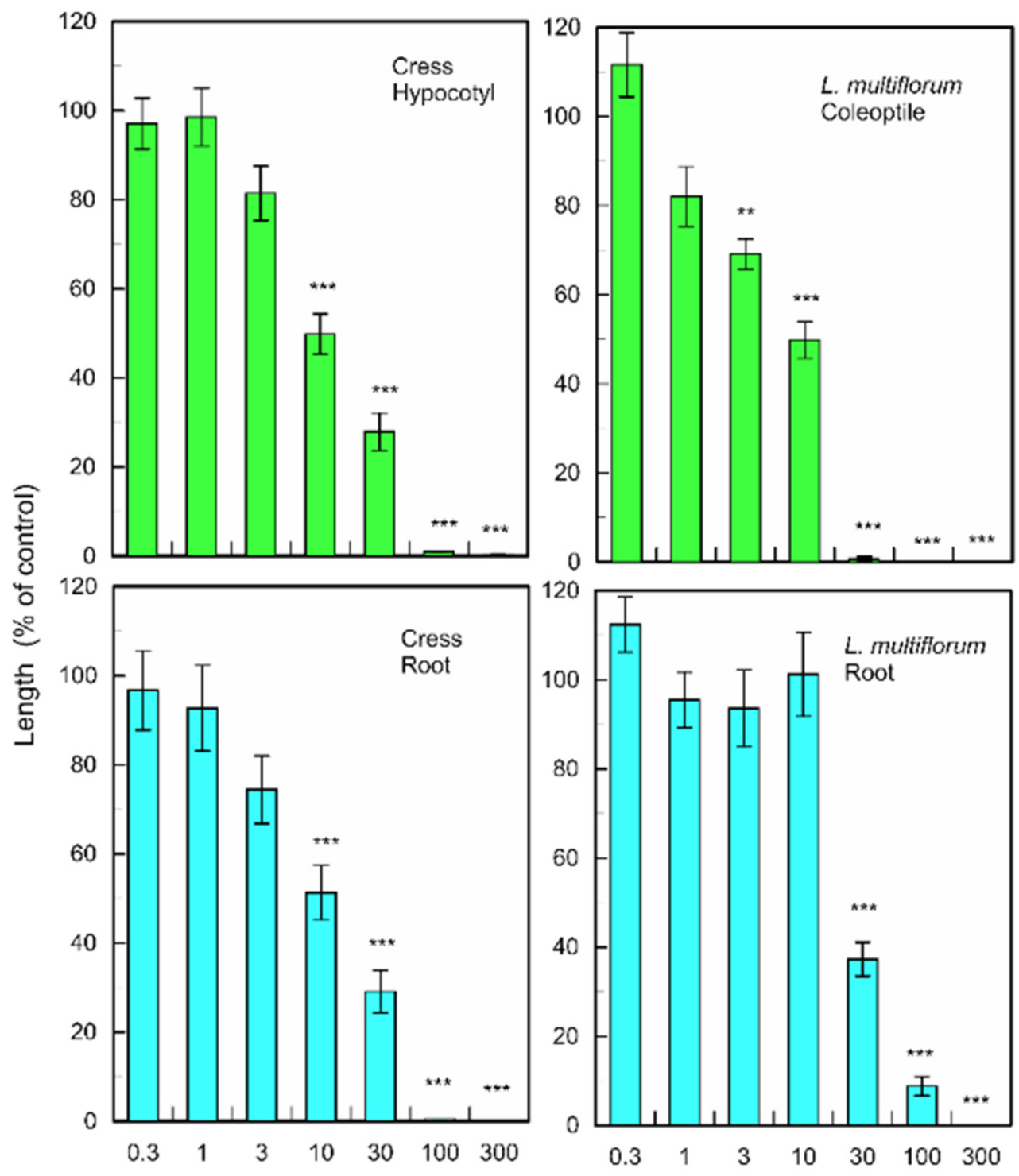

Concentration $(\mu \mathrm{M})$

Figure 7. Effects of 9-epi-blumenol $\mathrm{C}$ on root and hypocotyl/coleoptile growth of cress and L. multiflorum. Means $\pm \mathrm{SE}$ from 2 independent experiments with 10 seedlings for each determination are shown. Asterisks indicate significant differences between control and treatment: ${ }^{* *}, p<0.01$, $* * *, p<0.001$.

\section{Discussion}

Fallen leaf extracts of M. glyptostroboides have allelopathic activity against the growth of dicotyledonous plants (cress, lettuce, and alfalfa) and monocotyledonous weed plants (L. multiflorum, P. pretense, and V. myuros) (Figures 2 and 3). Considering $I C_{50}$ values (Table 1), roots of V. myuros were the most sensitive to the extracts among all of roots and hypocotyls/coleoptiles, and roots of $P$. pretense were the least sensitive among them. The sensitivity to the extracts of cress roots and hypocotyls, respectively, was the 3rd position of all of roots and hypocotyls/coleoptiles. As the stable germination rate of cress and its sensitivity to the extract, which was not high and not low among the six test plant species, a cress bioassay was used for the purification process of allelopathic substances in the extracts. 
Table 1. $I C_{50}$ values (mg dry weight equivalent extract per $\mathrm{mL}$ ) of the extracts of $M$. glyptostroboides fallen leaves on the growth of roots and hypocotyls/coleoptiles of bioassay plant species. The values were determined by the regression equation of the concentration-response as described in the text.

\begin{tabular}{ccc}
\hline Species & Root & Hypocotyl/Coleoptil \\
\hline Cress & 7.1 & 6.8 \\
Lettuce & 3.9 & 2.2 \\
Alfalfa & 7.2 & 7.4 \\
Lolium multiflorum & 10.6 & 7.6 \\
Phleum pretense & 12.4 & 8.1 \\
Vulpia myuros & 2.1 & 4.8 \\
\hline
\end{tabular}

Fallen leave extracts of $M$. glyptostroboides were separated as described in the process of Figure 3, and two active compounds were isolated. Based on the spectra data of NMR and specific rotation, the chemical structures of the compounds were identified as (+)rhododendrol and 9-epi-blumenol C (Figure 5). (+)-Rhododendrol and 9-epi-blumenol C were isolated from the most active two fractions-Fraction A and Fraction B, respectively, on the silica gel chromatography (Figure 4). Thus, those compounds may be main contributors to allelopathy of M. glyptostroboides fallen leaves. Allelopathic activity of the isolated compounds was determined with cress and L. multiflorum because cress was used for the purification process of the compounds, and L. multiflorum was selected due to the middle of the sensitivity to the extracts among three weed species (Table 1). Both compounds inhibited the growth of cress and L. multiflorum (Figures 6 and 7). However, considering $I C_{50}$ values of the compounds (Table 2), inhibitory activity of (+)-rhododendrol was 142-410 times greater than that of 9-epi-blumenol C.

Table 2. $I C_{50}$ values $(\mu \mathrm{M})$ of (+)-rhododendrol and 9-epi-blumenol $C$ of the growth of cress and L. multiflorum.

\begin{tabular}{ccccc}
\hline & \multicolumn{2}{c}{ (+)-Rhododendrol } & \multicolumn{2}{c}{ 9-epi-Blumenol C } \\
Species & Root & Hypocotyl & Root & Coleoptil \\
\hline Cress & 9.6 & 10.6 & 2780 & 2240 \\
Lolium multiflorum & 23.1 & 7.2 & 3290 & 2950 \\
\hline
\end{tabular}

Phenolic compound, (+)-rhododendrol has been isolated from Rhododendron genus species [29]. The compound was developed as a skin-whitening cosmetic since it works as a melanin production inhibitor. However, it was later found to cause leukoderma at a higher frequency, and its cosmetic products were withdrawn from the market $[30,31]$. The compound has recently isolated from the leaves of Cassia alata $\mathrm{L}$. and has been reported to act as an allelopathic agent [32].

$\mathrm{C}_{13}$-apocarotenoid compound, blumenol $\mathrm{C}$ was first isolated from leaves of Podocarpus blumei Endl. (Synonym, Nageia wallichiana (C.Presl) Kuntze) with blumenol A and B by Golaraith and Horn [33]. Blumenol C has stereoisomer (6R,9R)-blumenol $C$ and (6R,9S)blumenol C (9-epi-blumenol C) [28]. However, the absolute stereochemistry of blumenol C is not usually mentioned.

$\mathrm{C}_{13}$-apocarotenoids, also known as norisoprenoids, including blumenol $\mathrm{C}$, are synthesized by oxidative cleavage processes from $\alpha$ - and $\beta$-carotene, which are catalyzed by carotenoid cleavage enzymes [34]. Many $\mathrm{C}_{13}$-apocarotenoids have been reported to contribute important functions in plants such as growth, differentiation, and development, and the interactions with pollinators, herbivores, and pathogens [35-38]. Although (6R,9R)-blumenol $\mathrm{C}$ and 9-epi-blumenol $\mathrm{C}$ were not distinguished, the compound was reported to have antimicrobial and antifungal activity [39,40]. However, there had been no report on allelopathic activity of 9-epi-blumenol C. Thus, this paper is the first report showing allelopathic activity of 9-epi-blumenol C. The information of allelopathic activity of (6R,9R)-blumenol $C$ has not yet available. 
Blumenol $\mathrm{C}$ and its glycosides were found to accumulate in various plant roots with arbuscular mycorrhiza (AMF) colonization [34,41,42]. The accumulation of blumenol C induces to suppressed additional AMF colonization [42,43]. Most of the higher plants form a symbiosis with AMF [44], and AMF increases the ability of plants to uptake mineral nutrient and water and enhances the potential against pathogen attacks and several stress conditions $[45,46]$. Although allelopathic activity of 9-epi-blumenol $\mathrm{C}$ was not high compared to (+)-rhododendrol (Figures 6 and 7; Table 2), the compound may be able to degrade plant AMF colonization, which weakens the potential of other plants to absorb mineral nutrient and water, and the tolerance against pathogens and several stress conditions. It was also reported that root powder of Japanese knotweed (Fallopia japonica (Houtt.) Ronse Decraene) inhibited AMF vesicle formation in Ulmus spp. [47].

Perennial plants have potential to release allelopathic substances into their rhizosphere soil over several years through the root exudation and the decomposition process of plant litters. Those released compounds may be able to accumulate in the soil and disturb the germination and growth of other plant species [48-54]. M. glyptostroboides is a deciduous perennial conifer, and their fallen leaves accumulate on the soil and form a litter layer. Some of the secondary metabolites in the leaves can be released into rhizosphere soil during the decomposition process of the litter and act as allelopathic agents [20,23,55,56]. Allelopathic substances (+)-rhododendrol and 9-epi-blumenol C were isolated from the fallen leaves of M. glyptostroboides. Those compounds may be liberated into rhizosphere soil under the trees through the decomposition process of leaf litters and possibly act as allelopathic agents. Those compounds can disturb the growth and/or AMF colonization of neighboring plant species. In the present research, we have found that $M$. glyptostroboides has allelopathic potential, and (+)-rhododendrol and 9-epi-blumenol C may contribute to its allelopathy and increase competitive ability against neighboring plant species.

\section{Conclusions}

The extract of fallen leaves of M. glyptostroboides showed allelopathic activity. The extract was purified, and two active compounds were isolated. The chemical structures of the compounds were determined as (+)-rhododendrol and 9-epi-blumenol C. Those compounds may be the main contributors to the allelopathy of the fallen leaves of $M$. glyptostroboides and provide a competitive advantage to $M$. glyptostroboides through the inhibition of the growth of competing plants nearby. However, it is necessary to determine the concentrations of those compounds in the rhizosphere soil and to clarify the contribution of those compounds to the allelopathy.

Author Contributions: Conceptualization, H.K.-N.; methodology, Y.M., A.I., and H.K.-N.; software Y.M.; validation, K.S., and H.K.-N.; formal analysis, Y.M.; investigation, Y.M. and A.I.; data curation, K.S. and H.K.-N.; writing, H.K.-N.; visualization, H.K.-N.; supervision, H.K.-N. All authors have read and agreed to the published version of the manuscript.

Funding: This research received no external funding.

Institutional Review Board Statement: Not applicable.

Informed Consent Statement: Not applicable.

Data Availability Statement: No supporting data in this study.

Conflicts of Interest: The authors declare no conflict of interest.

\section{References}

1. Miki, S. On the change of flora in Eastern Asia since Tertiary Period. J. Jpn. Bot. 1941, 11, 237-303.

2. $\mathrm{Hu}, \mathrm{H} . \mathrm{H}$. On the new family Metasequoiaceae and on Metasequoia glyptostroboides, a living species of the genus Metasequoia found in Szechuan and Hupeh. Bull Fan. Mem. Inst. Biol. Bot. 1948, 1, 153-161.

3. Ma, J. The chronology of the "Living Fossil" Metasequoia glyptostroboides (Taxodiaceae): A review (1943-2003). Harv. Pap. Bot. 2003, 8, 9-18. 
4. Liu, Y.J.; Li, C.S.; Wang, Y.F. Studies on fossil Metasequoia from north-east China and their taxonomic implications. Bot. J. Linn. Soc. 1999, 130, 267-297. [CrossRef]

5. Liu, Y.J.; Arens, N.C.; Li, C.S. Range change in Metasequoia: Relationship to palaeoclimate. Bot. J. Linn. Soc. 2007, 154, 115-127. [CrossRef]

6. Florin, R. On Metasequoia, living and fossil. Bot. Notiser. 1952, 1, 1-29.

7. Florin, R. The distribution of conifer and taxad genera in time and space. Acta Horti. Bergiani. 1963, 20, $121-326$.

8. Wu, M.; Yao, L.; Ai, X.; Zhu, J.; Zhu, Q.; Wang, J.; Huang, X.; Hong, J. The reproductive characteristics of core germplasm in a native Metasequoia glyptostroboides population. Biodivers. Sci. 2020, 28, 303-313. [CrossRef]

9. Bate-Smith, E.C. Leuco-anthocyanins. 1. Detection and identification of anthocyanidins formed from leuco-anthocyanins in plant tissues. Biochem. J. 1954, 58, 122-125. [CrossRef]

10. Hattori, S.; Yoshida, S.; Hasegawa, M. Occurrence of shikimic acid in the leaves of Gymnosperms. Physiol. Plant. 1954, 7, 283-289. [CrossRef]

11. Juvik, O.J.; Nguyen, X.H.T.; Andersen, H.L.; Fossen, T. Growing with dinosaurs: Natural products from the Cretaceous relict Metasequoia glyptostroboides Hu \& Cheng-A molecular reservoir from the ancient world with potential in modern medicine. Phytochem. Rev. 2016, 15, 161-195. [CrossRef] [PubMed]

12. Suzuki, S.; Umezawa, T. Biosynthesis of lignans and norlignans. J. Wood Sci. 2007, 53, 273-284. [CrossRef]

13. Bajpai, V.K.; Rahman, A.; Kang, S.C. Chemical composition and anti-fungal properties of the essential oil and crude extracts of Metasequoia glyptostroboides Miki ex Hu. Ind. Crop Prod. 2007, 26, 28-35. [CrossRef]

14. Bajpai, V.K.; Kang, S.C. Antifungal activity of leaf essential oil and extracts of Metasequoia glyptostroboides Miki ex Hu. J. Am. Oil Chem. Soc. 2010, 87, 327-336. [CrossRef]

15. Asahi, M.; Sakan, F. Antifungal activity of diterpenes isolated from Metasequoia glyptostroboides Hu Et Cheng. J. Agr. Chem. Soc. Jpn. 1984, 58, 887-889.

16. Bajpai, V.K.; Kang, S.C. Antimycotic potential of a diterpenoid taxoquinone against Candida species isolated from Metasequoia glyptostroboides. Bangl. J. Pharmacol. 2014, 9, 154-160. [CrossRef]

17. Bajpai, V.K.; Kang, S.C. Antibacterial abietane-type diterpenoid, taxodone from Metasequoia glyptostroboides Miki ex Hu. J. Biosci. 2010, 35, 533-538. [CrossRef]

18. Bajpai, V.K.; Kang, S.C. Isolation and characterization of biologically active secondary metabolites from Metasequoia glyptostroboides Miki Ex Hu. J. Food Safety 2011, 31, 276-283. [CrossRef]

19. Nakatani, M.; Amano, K.; Shibata, K.; Komura, H.; Hase, T. Metaseol, a symmetrical diphenylmethane from Metasequoia glyptostroboides. Phytochemistry 1991, 30, 1034-1036. [CrossRef]

20. Belz, R.G. Allelopathy in crop/weed interactions-An update. Pest. Manag. Sci. 2007, 63, 308-326. [CrossRef]

21. Macías, F.A.; Molinillo, J.M.G.; Varela, R.M.; Galindo, J.G.G. Allelopathy-A natural alternative for weed control. Pest Manag. Sci. 2007, 63, 327-348. [CrossRef]

22. Chengxu, W.; Mingxing, Z.; Xuhui, C.; Bo, Q. Review on allelopathy of exotic invasive plants. Procedia Engin. 2011, 18, 240-246. [CrossRef]

23. Rice, E.L. Allelopathy, 2nd ed.; Academic Press: Orlando, FL, USA, 1984; 422p.

24. Duke, S.O.; Dayan, F.E.; Romagni, J.G.; Rimando, A.M. Natural products as sources of herbicide, current status and future trends. Weed Res. 2000, 40, 99-111. [CrossRef]

25. Cantrell, C.C.; Dayan, F.E.; Duke, O. Natural products as sources for new pesticide. J. Nat. Prod. 2012, 75, 1231-1242. [CrossRef] [PubMed]

26. Pan, H.; Lundgren, L.N. Rhododendrol glycosides and phenyl glucoside esters from inner bark of Betula pubescens. Phytochemistry 1994, 36, 79-83. [CrossRef]

27. Chattopadhyay, S.K.; Srivastava, S.; Sashidhara, K.V.; Tripathi, A.K.; Bhattacharya, A.K.; Negi, A.S. Betuligenol derivative with growth inhibition and antifeedant activity. Bioorg. Med. Chem. Lett. 2004, 14, 1729-1731. [CrossRef] [PubMed]

28. Matsunami, K.; Otsuka, H.; Takeda, Y. Structural revisions of blumenol C glucoside and byzantionoside B. Chem. Pharm. Bull. 2010, 58, 438-441. [CrossRef]

29. Harborne, J.B.; Williams, C.A. Leaf survey of flavonoids and simple phenols in the genus Rhododendron. Phytochemistry 1971, 10, 2727-2744. [CrossRef]

30. Ito, S.; Wakamatsu, K. Biochemical mechanism of rhododendrol-induced leukoderma. Int. J. Mol. Sci. 2018, 19, 552. [CrossRef]

31. Matsunaga, K.; Suzuki, K.; Ito, A.; Tanemura, A.; Abe, Y.; Suzuki, T.; Yoshikawa, M.; Sumikawa, Y.; Yagami, A.; Masui, Y.; et al. Rhododendrol-induced leukoderma update I: Clinical findings and treatment. J. Dermatol. 2021, 48, 961-968. [CrossRef]

32. Das, K.R.; Iwasaki, K.; Suenaga, K.; Kato-Noguchi, H. Isolation and identification of two phytotoxic compounds from the medicinal plant Cassia alata L. Weed Biol. Manag. 2020, 20,3-11. [CrossRef]

33. Galbraith, M.N.; Horn, D.H.S. Structures of the natural products blumenols A, B, and C. J. Chem. Soc. Chem. Commun. 1972, 1972, 113-114. [CrossRef]

34. Sun, G.; Putkaradze, N.; Bohnacker, S.; Jonczyk, R.; Fida, T.; Hoffmann, T.; Bernhardt, R.; Härtl, K.; Schwab, W. Six uridinediphosphate glycosyltransferases catalyze the glycosylation of bioactive $C_{13}$-apocarotenols. Plant Physiol. 2020, 184, 1744-1761. [CrossRef] 
35. Ohmiya, A.; Kishimoto, S.; Aida, R.; Yoshioka, S.; Sumitomo, K. Carotenoid cleavage dioxygenase (CmCCD4a) contributes to white color formation in chrysanthemum petals. Plant Physiol. 2006, 142, 1193-1201. [CrossRef]

36. Walter, M.H.; Floss, D.S.; Strack, D. Apocarotenoids: Hormones, mycorrhizal metabolites and aroma volatiles. Planta 2010, 232, 1-17. [CrossRef] [PubMed]

37. Nisar, N.; Li, L.; Lu, S.; Khin, N.C.; Pogson, B.J. Carotenoid metabolism in plants. Mol. Plant 2015, 8, 68-82. [CrossRef]

38. Hou, X.; Rivers, J.; León, P.; McQuinn, R.P.; Pogson, B.J. Synthesis and function of apocarotenoid signals in plants. Trends Plant Sci. 2016, 21, 792-803. [CrossRef] [PubMed]

39. Park, S.; Takano, Y.; Matsuura, H.; Yoshihara, T. Antifungal compounds from the root and root exudate of Zea mays. Biosci. Biotechnol. Biochem. 2004, 68, 1366-1368. [CrossRef]

40. Walter, M.H.; Strack, D. Carotenoids and their cleavage products: Biosynthesis and functions. Nat. Prod. Rep. 2011, 28, 663-692. [CrossRef]

41. Maier, W.; Schmidt, J.; Nimtz, M.; Wray, V.; Strack, D. Secondary products in mycorrhizal roots of tobacco and tomato. Phytochemistry 2000, 54, 473-479. [CrossRef]

42. Wang, M.; Schäfer, M.; Li, D.; Halitschke, R.; Dong, C.; McGale, E.; Paetz, C.; Song, Y.; Li, S.; Dong, J.; et al. Blumenols as shoot markers of root symbiosis with arbuscular mycorrhizal fungi. eLife 2018, 7, e37093. [CrossRef] [PubMed]

43. Adolfsson, L.; Nziengui, H.; Abreu, I.N.; Šimura, J.; Beebo, A.; Herdean, A.; Aboalizadeh, J.; Široká, J.; Moritz, T.; Novák, O.; et al. Enhanced secondary- and hormone metabolism in leaves of arbuscular mycorrhizal Medicago truncatula. Plant Physiol. 2017, 175, 392-411. [CrossRef] [PubMed]

44. Brundrett, M.C.; Tedersoo, L. Evolutionary history of mycorrhizal symbioses and global host plant diversity. New Phytologist. 2018, 220, 1108-1115. [CrossRef] [PubMed]

45. Smith, S.E.; Read, D.J. Mycorrhizal Symbiosis, 3rd ed.; Academic Press: London, UK, 2008; 815p.

46. Luginbuehl, L.H.; Menard, G.N.; Kurup, S.; Van Erp, H.; Radhakrishnan, G.V.; Breakspear, A.; Oldroyd, G.E.D.; Eastmond, P.J Fatty acids in arbuscular mycorrhizal fungi are synthesized by the host plant. Science 2017, 356, 1175-1178. [CrossRef] [PubMed]

47. Pinzone, P.; Potts, D.; Pettibone, G.; Warren, R. Do novel weapons that degrade mycorrhizal mutualisms promote species invasion? Plant Ecol. 2018, 219, 539-548. [CrossRef]

48. Mallik, A.U. Allelopathy and competition in coniferous forests. Environ. For. Sci. 1998, 54, 309-315. [CrossRef]

49. Kato-Noguchi, H.; Takeshita, S.; Kimura, F.; Ohno, O.; Suenaga, K. A novel allelopathic active substance in Ginkgo biloba. J. Plant Physiol. 2013, 170, 1595-1599. [CrossRef]

50. Kato-Noguchi, H.; Takeshita, S. Contribution of a phytotoxic compound to the allelopathy of Ginkgo biloba. Plant Signal. Behav. 2013, 8, e26999. [CrossRef]

51. Kato-Noguchi, H.; Kimura, F.; Ohno, O.; Suenaga, K. Involvement of allelopathy in inhibition of understory growth in red pine forests. J. Plant Physiol. 2017, 218, 66-73. [CrossRef]

52. Kato-Noguchi, H.; Kurniadie, D. Allelopathy and allelopathic substances of mango (Mangifera indica L.). Weed Biol. Manag. 2020, 20, 131-138. [CrossRef]

53. Kato-Noguchi, H. Phytotoxic substances involved in teak allelopathy and agroforestry. Appl. Sci. 2021, 11, 3314. [CrossRef]

54. Kato-Noguchi, H.; Kurniadie, D. Allelopathy of Lantana camara as an Invasive plant. Plants 2021, 10, 1028. [CrossRef] [PubMed]

55. Bais, H.P.; Weir, T.L.; Perry, L.G.; Gilroy, S.; Vivanco, J.M. The role of root exudates in rhizosphere interactions with plants and other organisms. Annu. Rev. Plant Biol. 2006, 57, 233-266. [CrossRef] [PubMed]

56. Bonanomi, G.; Sicurezza, M.G.; Caporaso, S.; Esposito, A.; Mazzoleni, S. Phytotoxicity dynamics of decaying plant materials. New Phytol. 2006, 169, 571-578. [CrossRef] 